\title{
The Reunion mantle plume is not oxidized
}

MARYJO BROUNCE ${ }^{1}$, E.M. STOLPER ${ }^{2}$, AND JOHN EILER ${ }^{2}$

${ }^{1}$ Department of Earth and Planetary Science, University of California Riverside, Riverside CA USA

${ }^{2}$ Division of Geological and Planetary Sciences, California

Institute of Technology, Pasadena CA USA

Glasses quenched from undegassed ocean island lavas erupted from volcanoes at Iceland, Hawaii, the Canary Islands, and Erebus have elevated $\mathrm{Fe}^{3+} / \Sigma \mathrm{Fe}$ ratios compared to glasses quenched from mid-ocean ridge basalts. This has been ascribed to elevated $f \mathrm{O}_{2}$ of their mantle plume sources, possibly because the plumes contain subducted, oxidized surface materials. To test this hypothesis, we present major and volatile element abundances and $\mathrm{Fe}^{3+} / \Sigma \mathrm{Fe}$ ratios of naturally glassy, olivine-hosted melt inclusions from the 2005 eruption of Piton de La Fournaise volcano, La Reunion, in the Indian Ocean. Lavas from La Reunion volcanoes have the least radiogenic Os isotopic compositions of any ocean island lavas, suggesting that the Reunion mantle plume taps a Redepleted mantle domain that has remained isolated since the Archean. This property, along with $\mathrm{Sr}-\mathrm{Nd}-\mathrm{Hf}-\mathrm{Pb}$ isotopic compositions similar to 'C-component' or FOZO, has been taken as evidence that the Reunion mantle plume contains little or no subducted surface materials and thus should not be more oxidized than mid-ocean ridge basalts.

Olivine hosts range from Fo82 to Fo84. After accounting for post-entrapment crystallization ("PEC"; 4.0-8.5\% correction), the Reunion melt inclusions have $6.3-8.5 \mathrm{wt} \%$ $\mathrm{MgO}, 0.25-0.70 \mathrm{wt} \% \mathrm{H}_{2} \mathrm{O}, 900-1200 \mathrm{ppm} \mathrm{S}$, and 0.09-0.16 $\mathrm{Fe}^{3+} / \Sigma \mathrm{Fe}$. The $\mathrm{H}_{2} \mathrm{O}$ contents vary at constant $\mathrm{K}_{2} \mathrm{O}$, consistent with $\mathrm{H}_{2} \mathrm{O}$ degassing and minimal crystallization at the time of entrapment. The presence of sulfide blebs in melt inclusions and $\mathrm{FeO}^{*}-\mathrm{S}$ systematics suggest that this magma was saturated with a sulfide liquid and $\mathrm{S}$ degassing was minimal. Both the PEC-corrected $\mathrm{Fe}^{3+} / \Sigma \mathrm{Fe}$ ratios and $\mathrm{Fe}^{3+} / \Sigma \mathrm{Fe}$ further corrected by $11-25 \%$ olivine addition to be in equilibrium with Fo90 $\left(\mathrm{Fe}^{3+} / \Sigma \mathrm{FeFo} 90=0.08-0.13\right)$ overlap with those of measured and primary Indian ocean MORB, suggesing that the Reunion plume and the Indian-ocean upper mantle both have $f \mathrm{O}_{2} \mathrm{~s}$ between QFM-1.2 and QFM +0.08 . We conclude that the Reunion mantle plume is not oxidized relative to the Indian-ocean upper mantle, perhaps due to an absence of recycled materials in the mantle plume. This also suggests that shared characteristics between Reunion and other ocean islands, such as melting of the upper mantle at relatively high pressures and temperatures, or crystallization in relatively thick crust, are not on their own sufficient to generate oxidized ocean island lavas. 